\title{
Analysis of Nano-hardness Distribution Near the Ferrite-martensite Interface in a Dual Phase Steel with Factorization of Its Scattering Behavior
}

\author{
Reon Ando $^{1)}$, Takashi Matsuno ${ }^{1)^{*}}$, Tomoko Matsuda ${ }^{2)}$, Norio Yamashita ${ }^{3)}$, Hideo Yokota ${ }^{3)}$, \\ Kenta Goto $^{4)}$, Ikumu WATANABE ${ }^{4)}$ \\ 1) Tottori University 2) Tottori Institute of Industrial Technology \\ 3) Riken Center for Advanced Photonics, Riken \\ 4) Research Center for Structural Materials, National Institute for Materials Science
}

Abstract: Herein, we investigated the local preliminary hardening of ferrite near the ferrite-martensite interfaces in a dual-phase (DP) steel. Geometrically necessary dislocations (GNDs), generated due to interfacial misfit between different phases, may cause preliminary hardening of ferrite around such interfaces. However, for nano-hardness distribution, the hardened zone was not evidently detected by scattering measurement. Thus, we factorized nano-hardness scattering to estimate the actual ferrite hardness near ferrite-martensite interfaces.

First, nano-hardness was measured around a martensite island using a conical nano-indenter in the DP steel containing $10 \%$ martensite by volume. Taking into account the scattering, the nano-hardness measurement converged to the hardness of ferrite, exceeding the distance corresponding to the nano-indenter radius. Thus, a preliminary hardening zone was not detected. Subsequently, the surface of the nano-indented microstructure was polished and observed using scanning electron microscopy (SEM) by analyzing electron back scattering diffraction (EBSD). This analysis confirmed the presence of the nano-indented microstructure under ferrite. Moreover, it established that the majority of the irregularly higher nano-hardness was caused by the buried martensite under ferrite. The value of the kernel average misorientation (KAM), which is proportional to the GND density for other irregularly higher nano-hardness points, was higher for the nano-indented microstructure as compared to that of the buried martensite. On the other hand, the ferrite was expanded under the nano-indented points for the majority of the irregularly lower nano-hardness, with some exceptions. Further, soft martensite was observed to induce irregularly lower nano-hardness locally around the interface.

Keywords: dual phase steel; grains and interfaces; scattering; nano-indentation; serial sectioning.
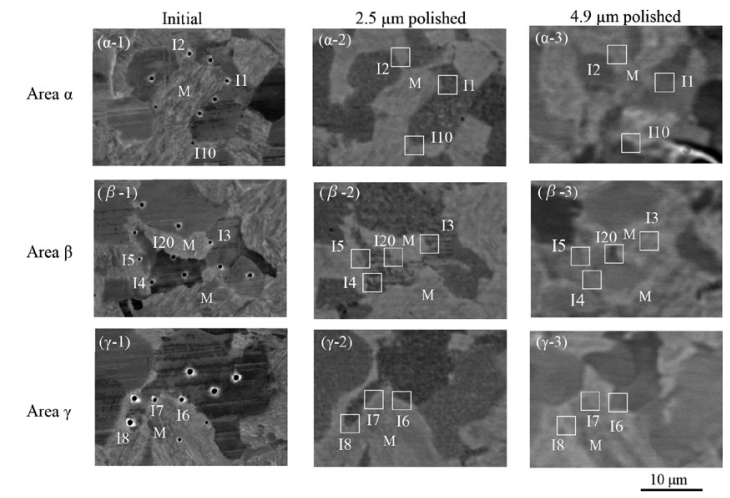

Received on Apr. 3, 2020 ; Accepted on Jun. 25, 2020

* Corresponding author. E-mail : matsu@tottori-u.ac.jp, Address : Tottori University, 4-101 Koyama-cho-minami Tottori Tottori $680-8552$ 


\title{
Dual Phase 鋼におけるフェライト・マルテンサイト界面近傍の ナノ硬さ分布とそのバラつき因子
}

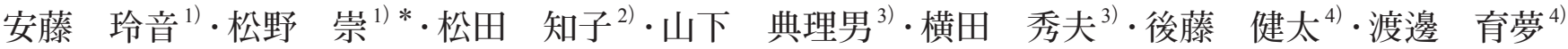

Analysis of Nano-hardness Distribution Near the Ferrite-martensite Interface in a Dual Phase Steel with Factorization of Its Scattering Behavior

Reon Ando, Takashi Matsuno, Tomoko Matsuda, Norio Yamashita, Hideo Yokota, Kenta Goto, Ikumu Watanabe

\section{1. 背景}

Dual Phase (DP) 鋼は硬質なマルテンサイトと軟質なフェ ライトの二つの組織から構成される。高い強度と延性を示 し，成形性と耐衝突性に優れるために ${ }^{1-3)}$ 自動車用鋼板と してよく用いられる鋼種である。1310 MPa級までの超高強 度鋼板が普及しつつある一方で，産業界における高強度・ 高延性のニーズは留まることがない。DP鋼においてもさ らなる高強度・高延性を目指して様々な分析が進められ ている。特にDP鋼中のマルテンサイトの分率・形態・硬 さとその機械的特性との関係が調査されてきた。例えば, Hasegawa $~^{4)}$ によればマルテンサイト分率が高くなるに つれてマルテンサイトの塑性歪みが増す。このような現象 は引張強さを増すということが報告されている5)。疲労破 壊挙動に関しても，Kurita ${ }^{6)}$ によってマルテンサイト変 形との強い相関が報告されている。他にも，マルテンサイ 卜の結晶粒度, 形状, 扎よび空間分布が強度や延性を支配 するとの報告は数多い ${ }^{7-11)}$ 。

さらに近年に打いては，フェライト・マルテンサイトの 界面近傍の力学的特性に注目される。Kadkhodapour ${ }^{12)}$ は界面近傍において第三相とも呼べるような硬化領域が 存在し，特に微細組織を有するDP鋼において強度を向上 させると報告している。この報告においてその原因はフェ ライト・マルテンサイト異相間の幾何学的に必要な転位 (Geometrically Necessary Dislocation : 以下では GNDと記す) による可動転位のピン止めとされており，その効果は有限 要素法解析による微視的な変形シミュレーションにより検

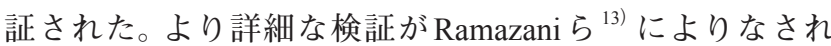
ており, 確かにフェライト・マルテンサイト界面近傍が特
別に“硬い”と思われる挙動を示すようである。これは微 細組織DP鋼における有効な強化機構として捉えられてい る。

他方, 微細組織でないDP鋼においては, これまでの知見 としてその強度におけるフェライト・マルテンサイト界面

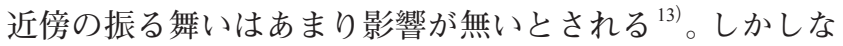
がら, 延性破壊という観点からするとDP鋼のボイド形成 はマルテンサイトとフェライトの界面から発生することが 多い ${ }^{14-17)}$ このことから, 微細組織に限らずDP鋼の延性破 壊のメカニズムを解き明かす上で, 界面近傍の局所的な機 械的特性を明らかにしておかなければならない。

このような背景のもとに，筆者らは有限要素法を使った ナノインデンテーションシミュレーションにより，あるべ きフェライト・マルテンサイト界面近傍のフェライトのナ ノ硬さ分布について調查をしている ${ }^{18)}$ 。この調査で, 実測 されたナノ硬さ分布の傾向を把握することができた。しか しながら，測定結果はバラつきが大きくその結果について 確証を得ることができていない。

そこで，本報に打いてはフェライト・マルテンサイト界 面近傍の局所的なナ八硬さ分布をマルテンサイトからの距 離と関連付けて調査をするとともに，そのバラつき因子を 分析する。筆者らの取り組み ${ }^{18)}$ に先んじて, 界面近傍の局

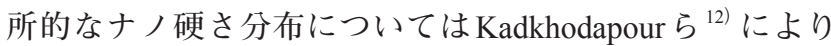
同様の測定が実施されている。その結果においても界面近 傍のナノ硬さバラつきはかなり大きなものとなっていた。 このようなバラつきはフェライトの直下に存在するマルテ ンサイト ${ }^{13)}$ ，あるいはGNDによる転位のピン止め効果に よるもの ${ }^{12)}$ と考察されるが，その検証は十分になされてい ない。後者のように界面近傍のフェライト中に局所的に硬

2020年4月3日受付 2020年6月25日受理（Received on Apr. 3, 2020 ; Accepted on Jun. 25, 2020)

1) 鳥取大学 (Tottori University)

2）鳥取県産業技術センター（Tottori Institute of Industrial Technology）

3) 理化学研究所光量子工学研究センター (Riken Center for Advanced Photonics, Riken)

4) 物質 ·材料研究機構構造材料研究拠点 (Research Center for Structural Materials, National Institute for Materials Science)

* Corresponding author. E-mail : matsu@tottori-u.ac.jp, Address : Tottori University, 4-101 Koyama-cho-minami Tottori Tottori 680-8552

(i) (C) 2020 The Iron and Steel Institute of Japan. This is an open access article under the terms of the Creative Commons Attribution license (https:// creativecommons.org/licenses/by/4.0/deed.ja). 
化した部位が存在するのであれば，延性破壊発生の起点と して極めて重要な役割を担うはずである。

本研究の目的とするところは, バラついたナノ硬さの中 より真にフェライト・マルテンサイト界面近傍の機械的特 性に起因するものを見出すことにある。表面より隠れたマ ルテンサイト，あるいはフェライトが大きなナノ硬さバラ つき因子となることから，これを特定して排除するために 本報ではナノインデンテーションの圧痕部をさらに研磨 することで圧痕を打ったフェライト部直下のフェライト・ マルテンサイト界面形状を可視化する。可視化された界面 形状を参照とし，フェライト・マルテンサイト近傍フェラ イト上のバラついたナノ硬さについて，それが圧痕直下の 界面の形状によるものか否かを判別していく。これによ り, 圧痕部となるフェライト直下の界面形状の変化を考慮 しても整合性のとれない硬化（あるいは軟化）域がフェラ イト中に存在するか否かを明らかにする。さらに, Electron Back Scattering Diffraction（EBSD）により圧痕周囲と上述 の研磨した部位を分析し，硬化（軟化）域の要因が GNDに よるものか検証する。

\section{2. 実験条件}

\section{$2 \cdot 1$ 供試鋼}

本研究で用いた試料の化学成分を Table 1 に示す。真空溶 解によって作成したインゴットに対し，1173 K で熱間圧延 することにより厚さ $6.0 \mathrm{~mm}$ の板材とした。この板材を 923 Kまで空冷した後，室温まで水冷した。

Fig.1はレペラー試薬 ${ }^{19)}$ を用いてエッチングした後の供

Table 1. Chemical compositions of the DP steel (mass\%).

\begin{tabular}{c|c|c|c|c|c}
\hline $\mathrm{C}$ & $\mathrm{Si}$ & $\mathrm{Mn}$ & $\mathrm{S}$ & $\mathrm{Al}$ & $\mathrm{N}$ \\
\hline 0.049 & 0.49 & 1.99 & 0.0013 & 0.029 & 0.0007 \\
\hline
\end{tabular}

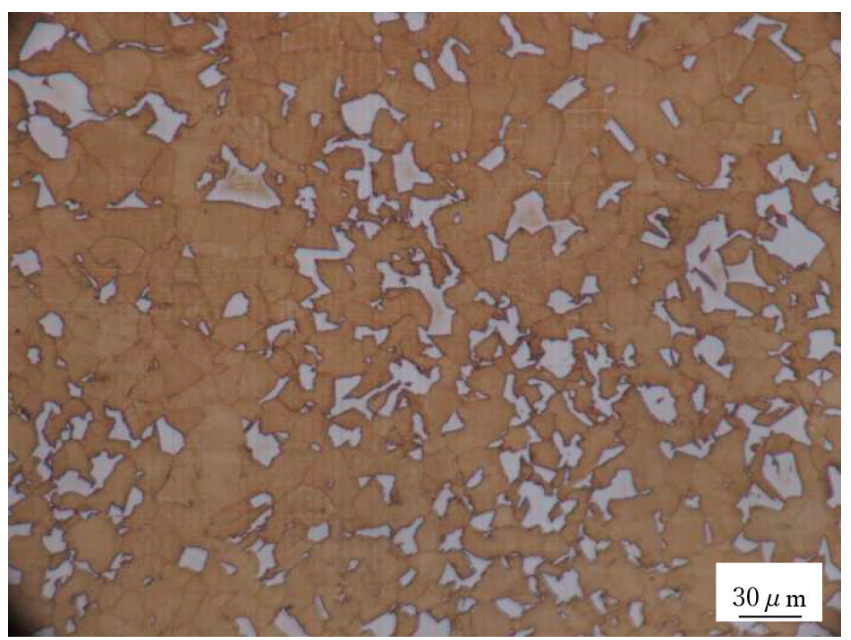

Fig. 1. Optical micrograph of the LePera-etched DP steel. White grains are martensite, while the others are ferrite. (Online version in color.)
試鋼の金属組織像（光学顕微鏡像）である。白い領域はマ ルテンサイトであり，他の暗い領域はフェライトである。 供試鋼には約 10\%の体積分率のマルテンサイトが含まれ， フェライトとマルテンサイトの平均粒径はそれぞれ 11.5 $\mu \mathrm{m}$ と $7.1 \mu \mathrm{m}$ である。ここで, 体積分率は画像解析によっ て算出した面積率とし，平均結晶粒径は線分法により算 出した。また，事前に後述のナノ硬さ測定と同一の装置て $10,000 \mu \mathrm{N}$ 荷重条件でマイクロ硬さを測定したところ，マ

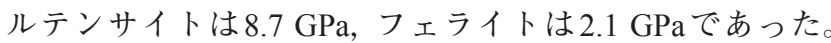
いずれも 3 点測った平均值となる。マルテンサイトとフェ ライトが比較的大きく広がった領域を狙ってナノ硬さを測 定した。

機械的特性は Table 2 に示す通りである。引張強度が若干 低いものの, $590 \mathrm{MPa}$ 級鋼材程度の機械的特性となってい る。

\section{$2 \cdot 2$ ナノインデンテーション}

Bruker社製の Hysitron T1950 TriboIndenterによりナノ硬 さを測定した。フェライト・マルテンサイト界面近傍を狙 い, $1000 \mu \mathrm{N}$ と $2000 \mu \mathrm{N}$ でナノインデンテーションを実施 した。ナノ硬さの測定には対頂角が $90^{\circ}$ である円錐圧子を 用いた。これは, Bercovich圧子のように圧痕の向きによっ て界面との距離が変化することを避けるためである。圧痕 とマルテンサイトとの距離を評価するにあたって, Fig.2に 示すように圧痕中心とフェライト・マルテンサイト界面法 線を結んだ長さを計測した。

本測定においては試料の凹凸に特に注意を払った。フェ ライト・マルテンサイト界面近傍のナノ硬さ測定において,

Table 2. Mechanical properties of the DP steel.

\begin{tabular}{c|c|c|c}
\hline $\begin{array}{c}\text { Yield stress } \\
{[\mathrm{MPa}]}\end{array}$ & $\begin{array}{c}\text { Tensile strength } \\
{[\mathrm{MPa}]}\end{array}$ & $\begin{array}{c}\text { Uniform } \\
\text { elongation [\%] }\end{array}$ & $\begin{array}{c}\text { Total elongation } \\
{[\%]}\end{array}$ \\
\hline 288 & 574 & 17.9 & 32.8 \\
\hline
\end{tabular}

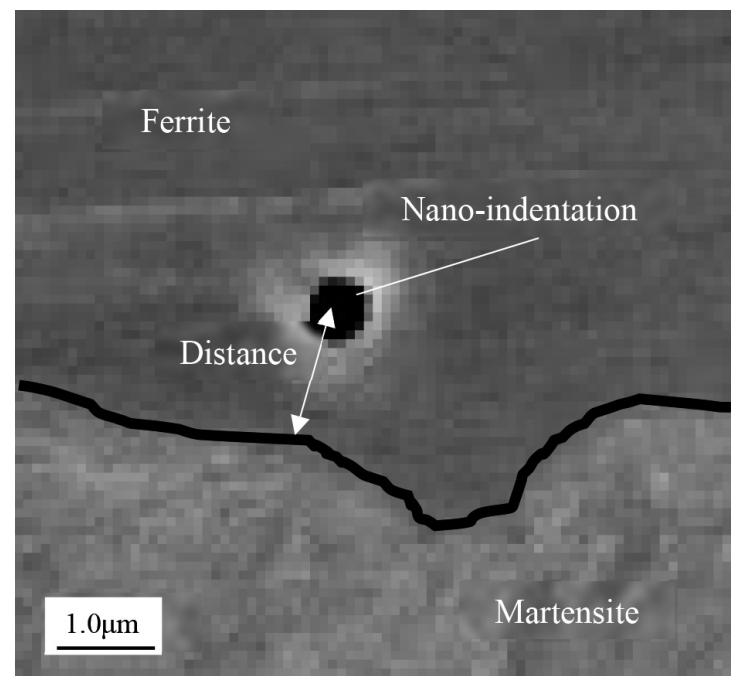

Fig. 2. Distance definition between nanoindentation and ferritemartensite interface in the DP steel. 
これら二相間の高低差がその結果に影響を与える。そこ で, 耐水ペーパーの４ 4000 まで研磨した後，ダイヤモンド 粒子の $1.0 \mu \mathrm{m}$ で叫凸を完全になくしたうえで，コロイダル シリカによる研磨を行った。Fig.3はナノインデンテーショ ン付属の走査プローブ顕微鏡によって測定したマルテンサ イト周囲の高さマップである。フェライト・マルテンサイ 卜界面近傍に揸いて, フェライトとマルテンサイトの高低 差がほとんどないことが確認できる。

ナノ硬さ測定位置は，フェライト・マルテンサイト界面 からの距離が $0.0 〜 2.0 \mu \mathrm{m}$ の地点を対象とした。また, 圧痕 同士の干渉を避けるために, 各ナノ硬さ測定位置はその中 心同士の距離として圧痕サイズの 5 倍以上離れた位置とし た。3つの領域 $\alpha$, 領域 $\beta$, 領域 $\gamma$ を設定したうえで，それ ぞれに対して6〜9点ナノ硬さを測定した。領域 $\alpha$ において は主として一つのマルテンサイト周囲のナノ硬さを測り, 領域 $\beta$ では複数のマルテンサイトを含むようにフェライ ト・マルテンサイト界面近傍のナノ硬さを測定した。いず れも圧痕荷重を $1000 \mu \mathrm{N}$ とした。領域 $\gamma$ では圧痕荷重の影 響を計るために一つのマルテンサイトに対して界面近傍の ナノ硬さを圧痕荷重 $2000 \mu \mathrm{N}$ として測定した。

\section{$2 \cdot 3$ 圧痕周囲の金属組織分析}

本報では，フェライト・マルテンサイト界面近傍のナノ 硬さばらつきに対し, 金属組織的な観点から考察する。そ

\section{Surface height [nm]}

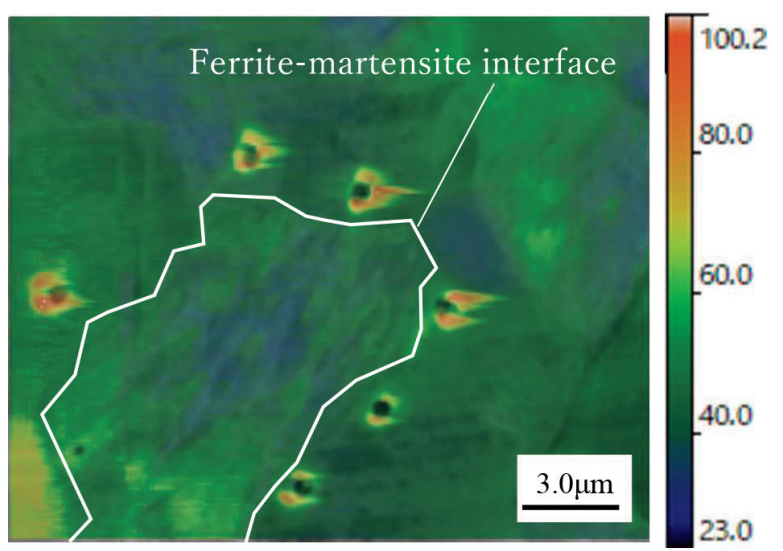

Fig. 3. Surface height map overlaid on the SEM image around a martensite grain, where nanoindentation was conducted near the interface. (Online version in color.)
のためにナノインデンテーションによる圧痕周囲の金属組 織, および表層研磨後に露出した内部金属組織像を分析す る。

分析にあたり, 日立ハイテク社製のSEM (SU5000)に Ametek社製のEBSDを組付けたものを用いた。圧痕周囲の SEM像を取得するとともにEBSDによって SEM撮影した 同様の視野でマルテンサイトとフェライトの結晶方位を 測定した。方位データである Inverse Pole Figure (IPF) に加 えてマルテンサイトとフェライトを識別するためにImage Quality (IQ) マップも取得した。また, 方位データからは Kernel Average Misorientation (KAM) 值を求め, これより GNDの分布を調べた。KAM值は各測定点における隣接す る周囲の測定点との差を平均したものとなる。GND密度 はKAM值にほぼ比例する事が知られる ${ }^{20)}$ 。なお, EBSDの ステップサイズは $0.04 \mu \mathrm{m}$ とした。

さらに, 圧痕部直下の微視組織を分析するために，ナノ インデンテーション後の表面を $2.50 \mu \mathrm{m}$, および $4.86 \mu \mathrm{m}$ ほ ど研磨し, その都度上記と同様のSEMとEBSD像を取得 した。ここで, 研磨には $0.05 \mu \mathrm{m}$ のアルミナを用い, さらに 精細な像を得るために, Cross-section Polisher (CP) 加工を 行った。

ここで, 研磨量の大きさを計測するにあたり，あらかじ め $20 \mathrm{~g}$ のVickers 圧痕を目印として設けておき, その大きさ の変化を測定した。Fig.4に研磨量と圧痕の大きさの関係を 模式的に示す。眓中, $d_{1}$ は研磨前のビッカース圧痕の対角 線長さ， $d_{2}$ は研磨のビッカース圧痕の対角線長さである。 そこから切削深さ $h$ は次式となる。

$$
h=\frac{d_{1}-d_{2}}{2 \sqrt{2} \sin 68^{\circ}}
$$

\section{3. 実験結果}

\section{3・1 SEMによる圧痕の観察}

Fig.5にナノインデンテーションによる圧痕とその周辺金 属組織のSEM像を示す。Fig.5においては研磨により圧痕 部の直下まで可視化したものを含む。一般にナノ硬さは フェライト・マルテンサイト界面からフェライト側に遠ざ

$d_{1}$
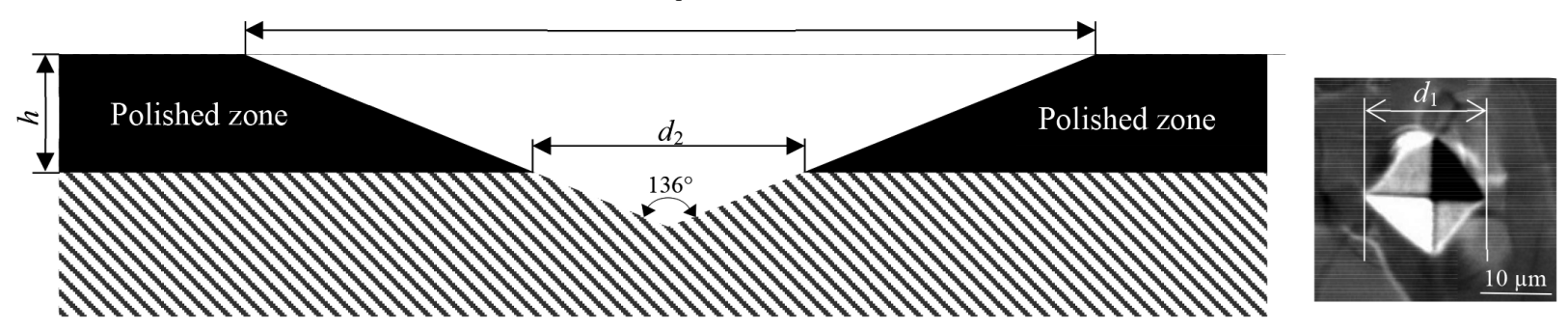

Fig. 4. Schematic image for evaluation method of the polishing depth by measuring Vickers indentation size. 
かるほど指数関数的に低下するが ${ }^{18)}$ ，ここでは後述のナノ 硬さバラつきを考察するために，この規則に適わないよう なバラついた硬さを示した圧痕に対して I1 から I8 までの 識別子を付けた。なお，I2やI7のようなバラつきに含まれ ないと思しきものも参照として例外的に識別子をつけてい る。フェライト・マルテンサイト界面と圧痕との距離は, 最も近傍のマルテンサイトからの距離を評価した。

Fig.5 $(\alpha-1),(\beta-1),(\gamma-1)$ から狙い通りにフェライト・ マルテンサイト界面近傍にナノインデンテーションを打て たことが確認できる。EBSDによるIPF＋IQマップにおい てフェライトとマルテンサイトはより識別しやすく，圧痕 下のフェライトとマルテンサイトの形状については $3 \cdot 2$ 節に後述することとする。

ナノインデンテーションの圧痕の平均直径は領域 $\alpha$ と 領域 $\beta$ (圧痕荷重 $1000 \mu \mathrm{N}$ ) で $0.569 \mu \mathrm{m}$, 領域 $\gamma$ (圧痕荷重 $2000 \mu \mathrm{N})$ で $1.17 \mu \mathrm{m}$ であった。

\section{3・2 EBSD測定によるIPF, IQ, KAMマップ}

Fig.6にEBSD測定によって得られた IQ + IPFマップ示 す。ここで, Fig.6に示す組織はFig.5のSEM像に全て一 致した領域となり, Fig.5におけるフェライト・マルテン サイトの判別がより分かり易くなっている。Fig.6 ( $\alpha-1)$ $(\alpha-3)$ から領域 $\alpha$ では, 圧痕 I1 近傍のマルテンサイトが直 下においては収縮・消滅していることが改めて確認できる。 逆に, 圧痕 I2 直下はマルテンサイトが存在している。Fig.6 $(\beta-1)-(\beta-3)$ より領域 $\beta$ では, 圧痕 I3, I4 直下はマルテ
ンサイト界面近傍のフェライトという状態を維持してい るが, 圧痕I5 直下はマルテンサイトが存在している。Fig.6 $(\gamma-1)-(\gamma-3)$ より領域 $\gamma$ では, 圧痕 I6 直下はマルテンサ イト界面近傍のフェライトという状態を維持しているが, 圧痕I7，I8はマルテンサイト直上となっている。

次に, Fig.7に同領域のKAMマップを示す。GNDは KAM值より算出されるため ${ }^{20)}$, このKAMマップをもって GNDの定性的な傾向をみる。Fig.7より全ての像において マルテンサイト部はKAM值が高く, フェライトはKAM值 が低い。フェライト・マルテンサイト界面近傍に打いて中 間的な KAM值を示すような場所もあるが，必ずしもフェ ライト・マルテンサイト近傍の KAM值が高いわけではな い。フェライト・フェライト粒界以外のフェライト中で KAM值が高い箇所も存在している。なお，フェライト・マ ルテンサイト界面近傍に打いて KAM值が高い領域は明ら かにステップサイズ $(0.04 \mu \mathrm{m})$ よりも大きい。したがって， ここで設定されたステップサイズは妥当であったとみなす ことができる。

\section{$3 \cdot 3$ ナノ硬さ}

Fig. 8 に $1000 \mu \mathrm{N}$ の圧痕荷重とした領域 $\alpha$ と領域 $\beta$ のナノ 硬さ測定結果を, Fig.9に2000 $\mu \mathrm{N}$ の圧痕荷重とした領域 $\gamma$ のナノ硬さ測定結果を示す。

Fig.8から, 領域 $\alpha$ においてフェライト・マルテンサイト 界面から遠ざかるにつれてナノ硬さは滑らかに下がって おりバラつきは少ない。他方, 領域 $\beta$ ではナノ硬さのバラ
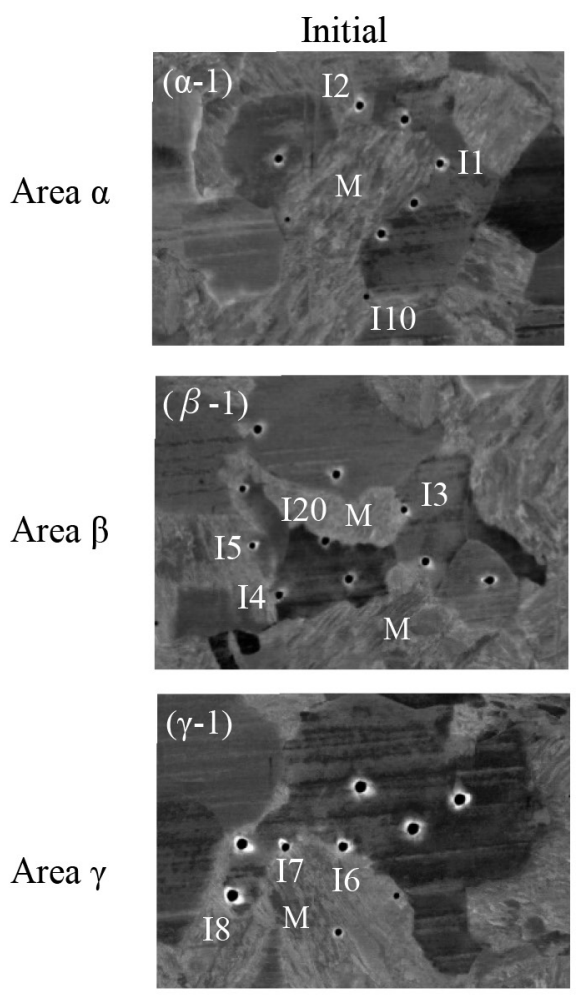

$2.5 \mu \mathrm{m}$ polished
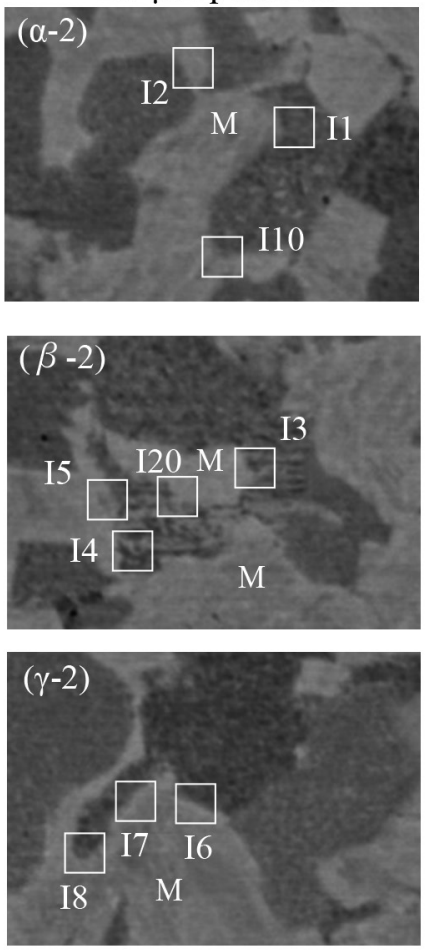

$4.9 \mu \mathrm{m}$ polished
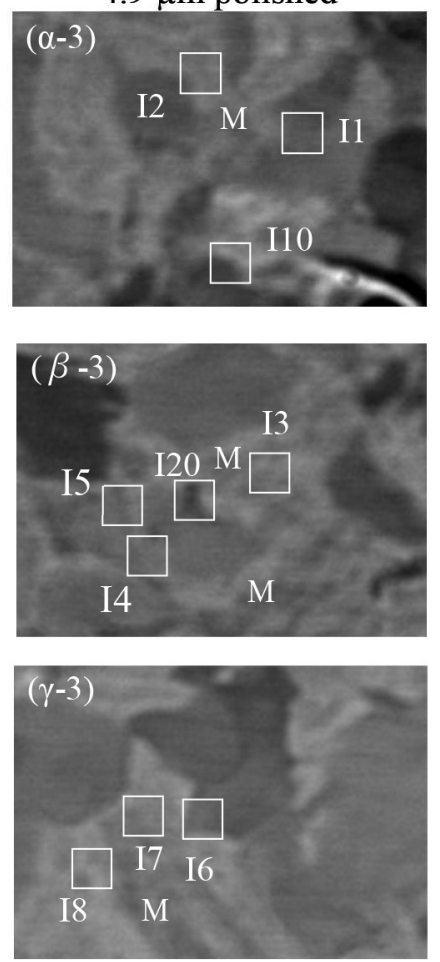

$10 \mu \mathrm{m}$

Fig. 5. SEM images of microstructures around the nanoindentations before and after polish. The symbol M denotes the martensite islands. 
つきが大きい。フェライト・マルテンサイト界面からの距 離に対して圧痕I4やI5のようなイレギュラーに高い硬さ を示す箇所が存在する。特に圧痕 I5 は界面と同等の硬さと なっている。領域 $\alpha$ の圧痕 $\mathrm{I} 1$ と領域 $\beta$ の圧痕 I3 ではフェラ イト・マルテンサイト界面からの距離がほぼ同じである が，圧痕I1に拈り硬さはI3のものよりも $1.5 \mathrm{GPa}$ 以上小 さい。また，I4とI5のナノ硬さバラつきを除けば，フェラ イト・マルテンサイト界面から $0.3 \mu \mathrm{m}$ 離れた地点におい て硬さの変化が収束している。この值は $3 \cdot 1$ 節に述べた圧 痕の大きさ (半径) に等しい。

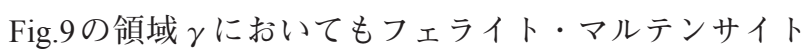
界面からの距離に対して一様にナノ硬さが減少しておら ず,バラつきが生じている。圧痕 I6 は圧痕 I7 よりもフェラ イト・マルテンサイト界面に近いが，I7の方がナノ硬さは 高い。圧痕I8はフェライトのナノ硬さ（フェライト・マル テンサイト界面より $1.0 \mu \mathrm{m}$ 以上離れた部位のナノ硬さ）よ

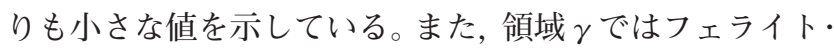
マルテンサイト界面から概ね $0.6 \mu \mathrm{m}$ ほど離れるとフェラ
イトのナノ硬さに収束をしており，領域 $\alpha$ の収束值よりも 大きい。この収束距離も概ね $3 \cdot 1$ 節に述べた圧痕の大きさ (半径)に等しいものとなっている。

\section{4. 考察}

3 章より圧痕の大きさ (半径) 以上にフェライト・マル テンサイト界面から遠ざかれば，バラつき部を除いてナノ 硬さは概ねフェライトのものに収束した。SEM像やEBSD 像で圧痕部として確認できる領域を主たる変形域と考えれ ば，この変形域 (圧痕) がマルテンサイトに及ばなくなっ たためにこのような収束を示したものと考えられる。これ は有限要素法によるシミュレーション結果に一致する ${ }^{18)}$ 。 フェライト・マルテンサイト界面近傍に硬化領域が存在す れば，この距離はもっと大きくなるはずなので，界面近傍 全域に渡るような硬化領域は存在しないことがナノ硬さの 結果より分かる。一方で，この結果はあくまでも平均的な ナノ硬さの傾向として読み取られたものであり, バラつき
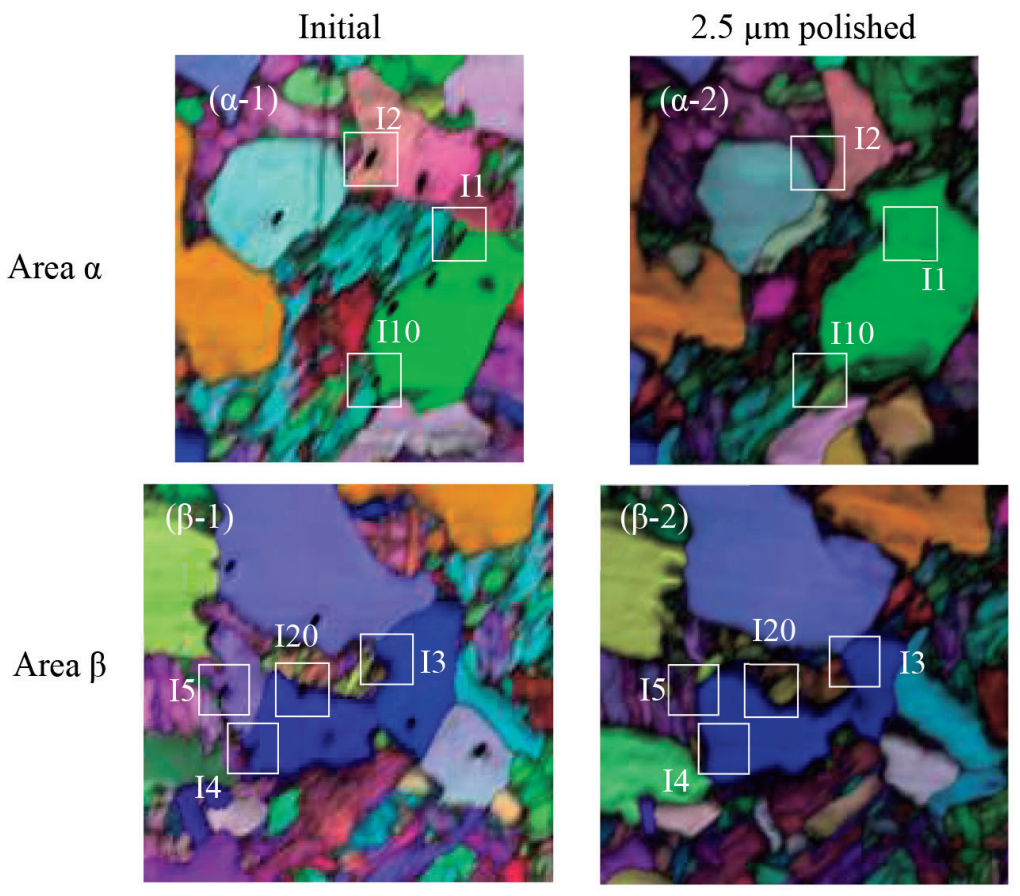

$4.9 \mu \mathrm{m}$ polished
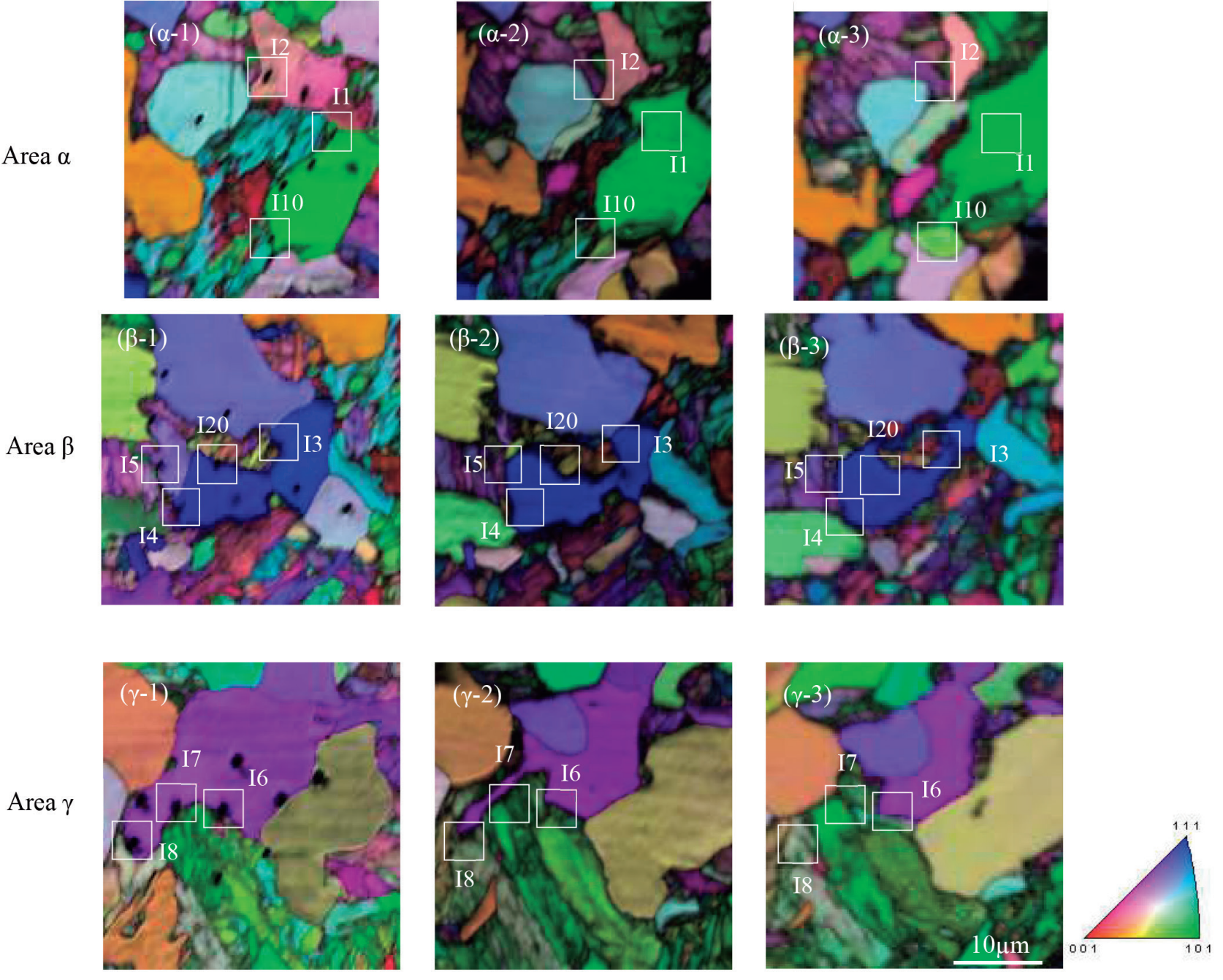

Fig. 6. Image quality and inverse pole figure (IQ+IPF maps) of the microstructures around the nanoindentations before and after polish. (Online version in color.) 
を含む結果となっている。当然のごとく，フェライト・マ ルテンサイト界面近傍のフェライトに扎いては，マルテン サイトの存在に起因してナノ硬さのバラつきが大きい。表
面上からは見えないマルテンサイトが圧痕直下に存在する 可能性が高く, 従来報告されるような異相界面近傍の GND も存在し得る。このバラついたナノ硬さについて, その要
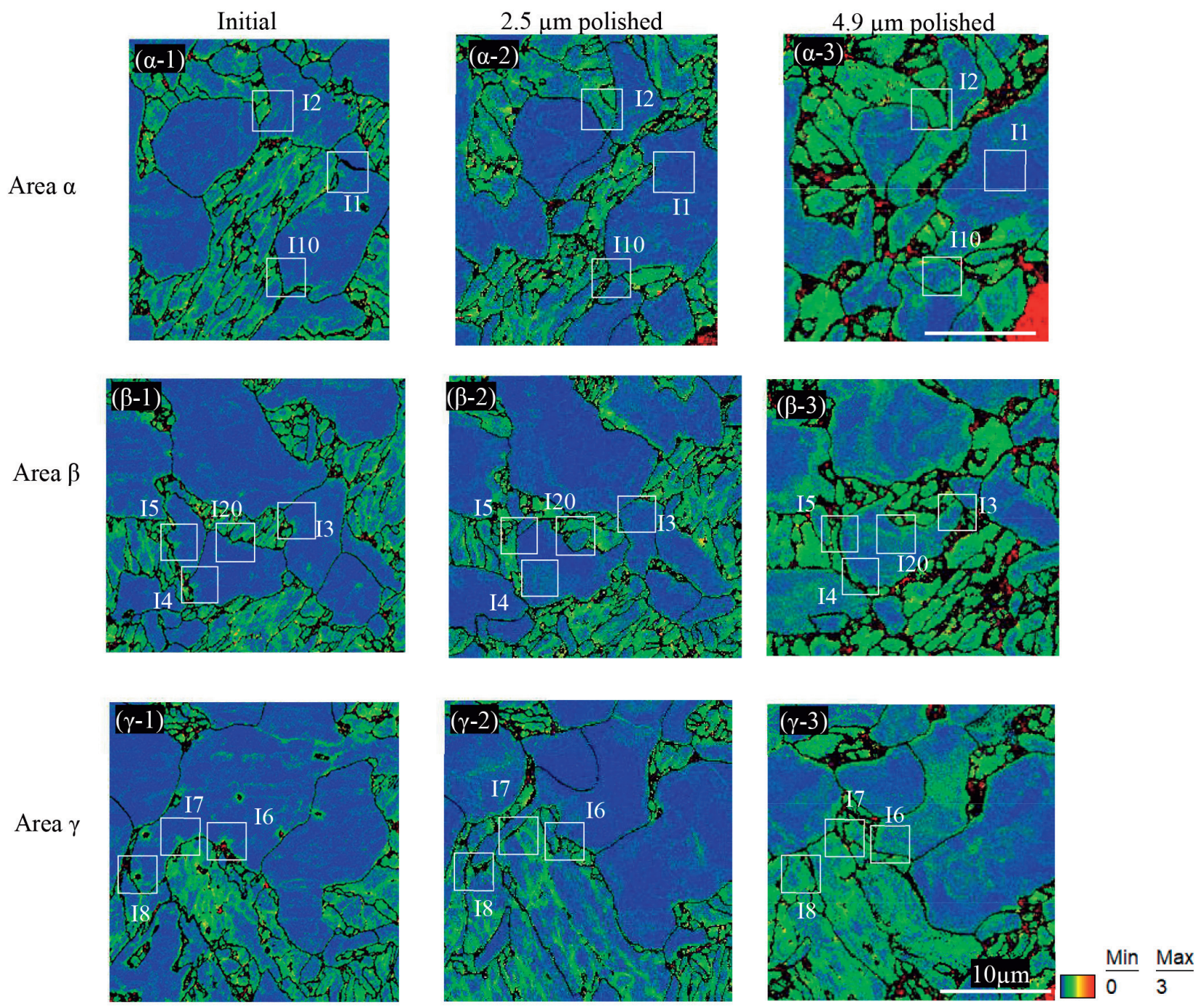

Fig. 7. Kernel Average Misorientation (KAM) maps of the microstructures around the nanoindentations before and after polish. The black lines indicate grain boundaries.

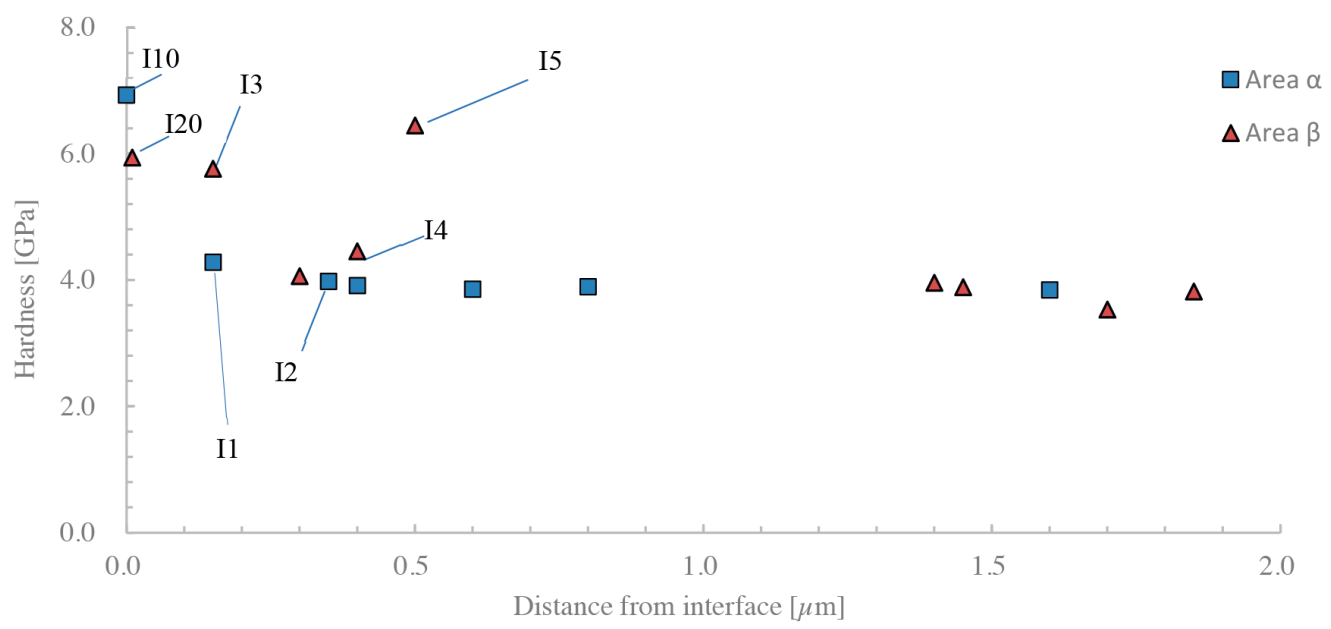

Fig. 8. Nano-hardness of ferrite near the ferrite-martensite interface in Area $\alpha$ and Area $\beta$ measured with $1000 \mu \mathrm{N}$ force. 
因を以下に考察していく。なお, 隣接する圧痕の加工硬化 部, あるいは圧痕部そのものまで変形域が及んだ場合には ナノ硬さ測定の結果は明らかに本来のものとずれてしま う。本報においては, Fig.6より圧痕周囲のIQが低い箇所 (明らかな変形部) が複数の圧痕で重なる部分はみられな い。そのため, ナノ硬さ測定結果に対する隣接圧痕の影響 は小さいものとして議論を進める。

まず, 領域 $\alpha$ にいて分析をする。領域 $\beta$ の圧痕I3の 結果と比較するに, 領域 $\alpha$ の圧痕I1においてはフェライ ト・マルテンサイト界面からの距離がほぼ等しいにもかか わらずナノ硬さの值が小さい。これはFig.5と6の ( $\alpha-2)$, $(\alpha-3)$ より圧痕I1の直下ではフェライトの領域が広がっ ており，柔らかいフェライトがナノ硬さ測定結果に影響 を及ぼしたためであると思われる。Fig.5（ $\alpha-2)$, あるいは Fig.6 ( $\alpha-2)$ の $2.5 \mu \mathrm{m}$ という研磨量は圧痕深さに対しては 大きいため，この部位で観察されたフェライトが圧痕直下 の変形域のものを直接示しているとは限らない。上記の議 論は, $2.5 \mu \mathrm{m}$ 研磨した部位と同様に圧痕直下の変形域にお いてもフェライト部が広がっていることを仮定して進め ている。圧痕I1 とは逆に, 圧痕I2 はFig.6 ( $\alpha-2)$ より圧痕 の直下にはマルテンサイトが存在する。しかしながら, 圧 痕I 2 に打けナナノ硬さはフェライトとほぼ同程度の硬さ となっている。このような想定よりもナノ硬さが低いとい う挙動についてはその詳細な理由は現在のところ分からな い。压痕直下に限ってフェライト・マルテンサイト界面が 圧痕より離れた位置となるような形状となっていたことが 一つの理由として考えられる。あるいは, 鋼種は異なるも のの DP 鋼中のマルテンサイトは特にその界面において炭 素量がバラつく事が報告されており ${ }^{21)}$, 界面付近のマルテ ンサイトに局所的に軟質な部位が圧痕下に存在していたと も考えられる。

続いて, 領域 $\beta$ について分析をする。圧痕I3について
はFig.6（ $\beta$-2）よりその下部においても界面の位置はあま り変化していない。領域 $\beta$ に打ける界面直上の硬さ（圧痕 I20）と比較するとその值が近いために硬めの評価となる。 領域 $\alpha$ に打る界面直上の硬さ（圧痕I10）と比較すれば 界面からの距離 $0.0 \mu \mathrm{m}$ (圧痕 I10）と $0.4 \mu \mathrm{m}$ (圧痕 I2）のナ ノ硬さを結んだ直線上に位置している。マルテンサイト界 面からの距離に応じて指数的に硬さは減少するので ${ }^{18)}$, 領 域 $\alpha$ でのナノ硬さ測定結果をもってしても硬めの評価で ある。Fig.7 ( $\beta-1)$ から圧痕I3の周囲はKAM值が高く, こ れに伴いGND密度も高い。これがナノインデンテーショ ンにより生成されたものか, 元から存在していたものかは 判断することはできないが, 圧痕下のマルテンサイトの存 在有無以外の因子として, もともと存在していたものがナ ノ硬さとして表机た可能性があるものと思われる。Fig.6 ( $\beta$-2) より領域 $\beta$ の圧痕I20の下部には寧ろマルテンサイ トが存在しているが領域 $\alpha$ の圧痕I10の結果よりも $1 \mathrm{GPa}$ 程度もナノ硬さが低い。前述のように, 界面近傍のマルテ ンサイトの炭素量バラつきが原因と考えられる。圧痕 I5に おいてはほぼ界面上の圧痕I 20 並みのナノ硬さであるが, これはFig.6 ( $\beta$-2) より $2.5 \mu \mathrm{m}$ 研磨部ではほぼ圧痕位置が マルテンサイトとなっており, その直下にマルテンサイト が存在していたためであると思われる。圧痕I4については 逆にフェライトが压痕下に広がるような分布であるにもか かわらず，ナノ硬さはフェライトのものよりも若干高い。 Fig.7 ( $\beta$-1) より界面周囲にKAM值が高い部位が存在して おり, 圧痕 $\mathrm{I} 3$ と同様の理由でナノ硬さが高くなった可能性 が示唆される。

領域 $\gamma$ の圧痕I6は Fig.6 $(\gamma-1),(\gamma-2)$ より研磨しても ほぼ圧痕と界面との位置関係に変化が見られない。そのた め, 界面直上のナノ硬さとフェライトの硬さの概ね中間的 なナノ硬さを示す結果になったものと思われる。圧痕 I7 は ナノ硬さがイレギュラーに高いが, Fig.6 $(\gamma-2)$ より圧痕

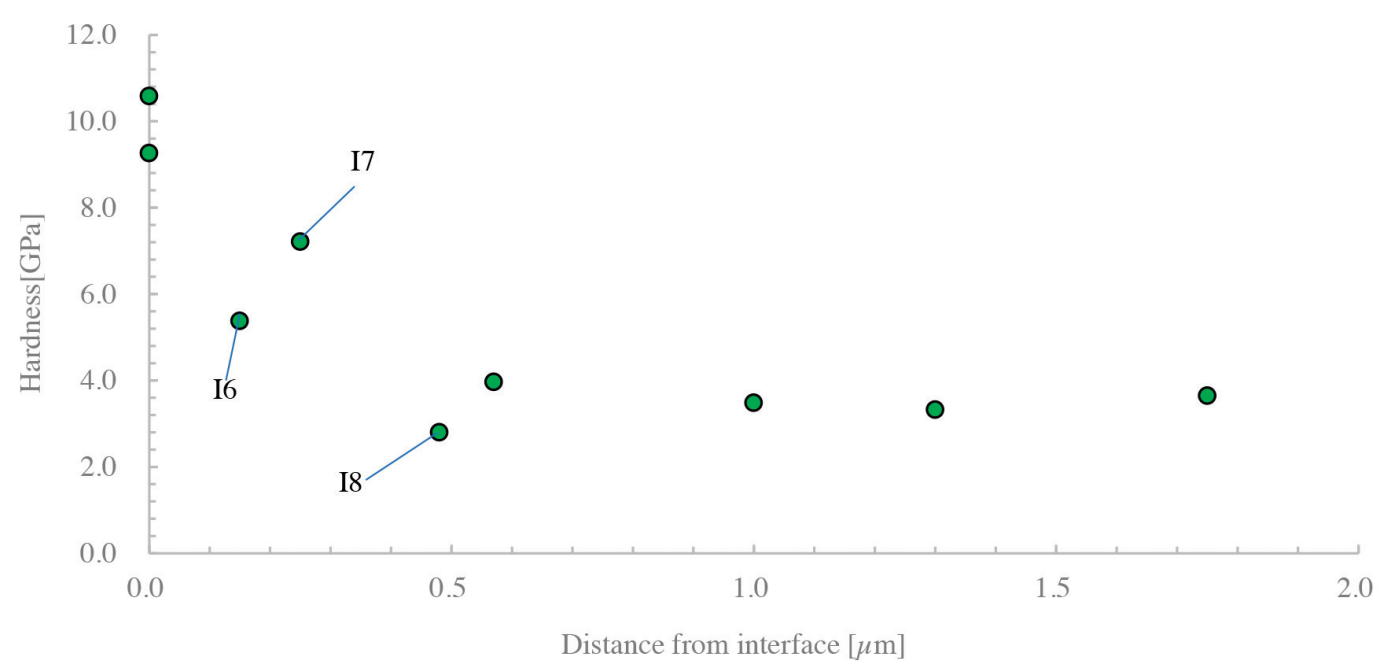

Fig. 9. Nano-hardness of ferrite near the ferrite-martensite interface in Area $\gamma$ measured with $2000 \mu \mathrm{N}$ force. (Online version in color.) 
直下に存在するマルテンサイトがその原因であることが分 かる。圧痕I8についてはマルテンサイトが直下に存在する にもかかわらずナノ硬さが低い。上述の界面近傍のマルテ ンサイト硬さバラつきが顕著に発現した可能性があるが, マルテンサイトのナノ硬さがフェライトよりも低いことに なるためフェライトのナノ硬さが低い側へバラついた可能 性も示唆される。領域 $\gamma$ においては領域 $\alpha$ と $\beta$ に比べれば 圧痕荷重が 2 倍であるが，フェライト・マルテンサイト界 面直上を除いてナノ硬さ測定結果に大きな違いは見られな かった。

上記の結果をまとめると，今回対象としたDP鋼におい ては従来報告されるようなフェライト・マルテンサイト界 面近傍全域に渡るような硬化部は存在しなかった。バラつ き因子を探るに，ナノ硬さが高い部位は圧痕部の下に存在 するマルテンサイトにより説明ができる。Fig.7の KAMの 分布も界面近傍において特段の高い值を示さない。一部, 圧痕直下のマルテンサイトでは説明できないバラつきが存 在しており，高い側のナノ硬さバラつきに対してはKAM (GND) の影響が示唆された。寧ろマルテンサイトの炭素 量バラつきと思しき界面近傍の軟化部 (界面近傍としては 低いナノ硬さ）が目立つ結果となった。界面近傍の硬化領 域が着目されてきたが，本報ではマルテンサイトの3次元 的な形態によるナノ硬さ部のバラつき因子を一つ一つ分析 する事で，新たに界面近傍マルテンサイトの軟化部存在の 可能性を示すことができたものと考える。このメカニズム の検証も含め, 力学的特性に対する影響については今後調 査を進めていきたい。

\section{5. 結言}

本報に打いてはDP鋼を対象に，フェライト・マルテン サイト界面近傍のフェライトのナノ硬さ分布とそのバラつ き因子を調査した。これはマルテンサイトとの界面部近傍 のフェライトが硬化しているとの知見に基づき，この硬化 以外のマルテンサイトの3 次元的な形態に伴う因子を排し たナノ硬さ分布を得ることを目的としている。2段階の研 磨とSEM・EBSD測定によりナノ硬さ測定のバラつき因子 を排除することで，以下の知見を得た。

（1）フェライト・マルテンサイト界面より圧痕の半径程度 離れると, バラついた值を除いてナノ硬さはフェライ トの值に収束した。

（2）ナノ硬さが高い側へバラついた圧痕において，その下 部にはマルテンサイトが存在していた。しかしなが ら，マルテンサイトが圧痕下に存在しない場合もあつ た。このような場合，圧痕周囲のフェライトは高い KAM值を示した。従来報告される GNDによる硬化領 域は界面近傍の一部に存在するものと考えられる。

（3）ナノ硬さが低い側へのバラつきに扎てて，多くは圧痕
下にフェライトが広がった（圧痕が界面から離れた） 状態となっていた。しかしながら，逆にマルテンサイ 卜が存在する場合もあったため, 界面近傍のマルテン サイトの軟化部の存在が示唆された。

\section{謝辞}

本研究を進めるにあたり，日本鉄鋼協会の第27回 鉄鋼研究助成, および天田財団奨励研究助成 (No. AF2018035-C2）による補助を受けた。ここに謝意を表する。

\section{文献}

1 ) M.Takahashi: Nippon Steel Tech. Rep., 88(2003), 2. http://www. nssmc.com/en/tech/report/nsc/pdf/n8802.pdf, (accessed 2020-10-08)

2 ) J.Lee, S.-J.Lee and B.C.De Cooman: Mater. Sci. Eng. A, 536(2012), 231. https://doi.org/10.1016/j.msea.2012.01.003

3 ) A.S.Khan, M.Baig, S.-H.Choi, H.-S.Yang and X.Sun: Int. J. Plast., 30-31(2012), 1. https://doi.org/10.1016/j.ijplas.2011.08.004.

4 ) K.Hasegawa, Y.Toji, H.Minami, H.Ikeda, T.Morikawa and K.Higashida: Tetsu-to-Hagané, 98(2012), 320 (in Japanese). https:// doi.org/10.2355/tetsutohagane. 98.320

5 ) P.-H.Chang and A.G.Preban: Acta Metall., 33(1985), 897. https://doi. org/10.1016/0001-6160(85)90114-2

6 ) M.Kurita, K.Toyama, S.Nomura and K.Kunishige: Tetsu-toHagané, 81(1995), 1091 (in Japanese). https://doi.org/10.2355/ tetsutohagane1955.81.11 1091

7 ) H.Lyu, A.Ruimi and H.M.Zbib: Int. J. Plast. 72(2015), 44. https:// doi.org/10.1016/j.ijplas.2015.05.005

8 ) S.Sun and M.Pugh: Mater. Sci. Eng. A, 335(2002), 298. https://doi. org/10.1016/S0921-5093(01)01942-6

$9)$ T.Matsuno, T.Yoshioka, I.Watanabe and L.Alves: Int. J. Mech. Sci., 163(2019), 105133(15pages). https://doi.org/10.1016/j.ijmecsci.2019. 105133

10) D.Das and P.P.Chattopadhyay: J. Mater. Sci., 44(2009), 2957. https:// doi.org/10.1007/s10853-009-3392-0

11) A.Fillafer, E.Werner and C.Krempaszky: Mater. Sci. Eng. A, 708(2017), 556. https://doi.org/10.1016/j.msea.2017.10.005

12) J.Kadkhodapour, S.Schmauder, D.Raabe, S.Ziaei-rad, U.Weber and M.Calcagnotto: Acta Mater, 59(2011), 4387. https://doi.org/10.1016/ j.actamat.2011.03.062

13) A.Ramazani, K.Mukherjee, A.Schwedt, P.Goravanchi, U.Prahl and W.Bleck: Int. J. Plast., 43(2013), 128-152. https://doi.org/10.1016/ j.ijplas.2012.11.003

14) G.Avramovic-Cingara, Y.Ososkov, M.K.Jain and D.S.Wilkinson: Mater. Sci. Eng. A, 516(2009), 7. https://doi.org/10.1016/j.msea.2009. 03.055

15) M.Kikuzuki, K.Hayashi, Y.Tsunemi, S.Yabu and T.Matsuno: Tetsuto-Hagané, 106(2020), 244 (In Janpanese). https://doi.org/10.2355/ tetsutohagane.TETSU-2019-111

16) T.Matsuno, D.Maeda, H.Shutoh, A.Uenishi and M.Suehiro: ISIJ Int., 54(2014), 938. https://doi.org/10.2355/isijinternational.54.938

17) T.Matsuno, C.Teodosiu, D.Maeda and A.Uenishi: Int. J. Plast., 74(2015), 17. https://doi.org/10.1016/j.ijplas.2015.06.004

18) T.Matsuno, R.Ando, N.Yamashita, H.Yokota, K.Goto and I.Watanabe: Int. J. Mech. Sci., 180(2020), 105663. https://doi.org/10.1016/ j.ijmecsci.2020.105663

19) F.S. LePera: J. Met., 32(1980), 38

20) D.P.Field, P.B.Trivedi, S.I.Wright and M.Kumar: Ultramicroscopy, 103(2005), 33. https://doi.org/10.1016/j.ultramic.2004.11.016

21) C.P.Scott, B.Shalchi Amirkhiz, I.Pushkareva, F.Fazeli, S.Y.P.Allain and H.Azizi: Acta Mater, 159(2018), 112. https://doi.org/10.1016/ j.actamat.2018.08.010 